\title{
BIREYSEL EMEKLILIK SISTEMI VE ETKILI iLETIŞiM BiçiMI OLARAK REKLAM
}

\author{
Ömer AÇIKGÖZ*, Merve KARDELEN BILIR**
}

\begin{abstract}
Özet
20. Yüzyılın sonunda, yaşlı nüfusun artış hızındaki değişim ve tıbbi teknolojinin yardımıyla nüfusun yaşama süresinin uzaması gibi demografideki hızlı değişimlerle birlikte, emeklilik reformları sosyal politika alanındaki en tartışmalı konularından biri olmuştur. Emeklilik yaşı ve emekli maaşı alma hakkı gibi emeklilik sistemlerinin temel göstergeleri birçok ülkede değişmiştir; bu değişen politikaların ana nedeni, mevcut emeklilik politikalarının mali yönetim krizinin bir sonucu olarak ortaya çıkmasıdır. Bu bağlamda, 2001 yılından başlayarak, Türkiye'deki bireysel emeklilik politikasının yapısı, gönüllü katılımdan zorunlu katılıma doğru değişmiştir. Aynı zamanda, Bireysel Emeklilik Sistemi'nin (BES) ülke ekonomisinde çok önemli bir mekanizma olarak önemi, Türkiye hükümeti tarafından sıklıkla vurgulanmaktadır. Bu noktada, bu makalenin ana amacı, Türkiye'de Bireysel Emeklilik Sistemi (BES) ile reklamları arasındaki etkileşimli ilişkiyi analiz etmektir.
\end{abstract}

Anahtar Kelimeler: Bireysel Emeklilik Sistemi, reklam, etkili iletişim, Türkiye, iletişim. 


\title{
THE INDIVIDUAL PENSION SYSTEM AND ADVERTISING AS EFFECTIVE COMMUNICATION
}

\author{
Ömer AÇIKGÖZ*, Merve KARDELEN BiLiR**
}

\begin{abstract}
At the end of the 20th century, with rapid changing in demography like increasing in the population aging and the prolonged life expectancy by the help of medical technology in the world, pension reforms have been one of the most contradictive issues in the field of social policy. The basic indicators of pension systems such as retirement age and the period of entitlement to pension have been changed in many countries; the main reason for these changing policies has been expounded as a result of financial management crisis of the existing pension policies. In this regard, from 2001 to onwards, the structure of the individual pension policy in Turkey has changed from voluntary participation towards compulsory participation. At the same time, the importance of the Individual Pension System (BES) as a very important mechanism in the national economy is emphasized frequently by the Turkish government. In this point, the main purpose of this article is about the interactive relationship between the Individual Pension System (BES) in Turkey and its advertisements.
\end{abstract}

Keywords: The Individual Pension System, advertising, effective communication, Turkey, communication. 


\section{Giriş}

Kaynak, alııı, ileti, kanal, dönüt ve bağlam olarak sıralanan iletişimin öğeleri birbiriyle kaçınılmaz bir etkileşim halinde bulunurlar. Bu sebeple bir mesajın yorumlanması süreci iletinin kaynağı, ileti, hedef alıcı ve iletişimin gerçekleştiği toplumsal ve kültürel yapının özellikleriyle birlikte değerlendirilmelidir. Reklamlar aracılığı ile iletilmek istenen mesajlar, reklamların çeşitli semboller aracılı̆ıyla kodlanması ile oluşturulmaktadır. Mesaj ilk olarak tüketiciye "ne" söyleneceği ve tüketicinin bu tanımı "nası"” yorumlayacağı üzerine kuruludur. Tüketiciye iletilmek istenen mesajın içeriğinde öncelikle alınacak hizmetin veya malın tüketiciye sağlayabileceği yararlar ve bu yararların hangi yollarla tüketiciye iletileceği yer almaktadır.

Bu bağlamda tüketicileri mal veya hizmetler hakkında bilgilendirerek, onların tutum ve davranışlarını reklamın hedefleri ekseninde oluşturmak reklamın amaçları arasındadır. William J. McGuire (1978) tarafından tanımlanan etkileyici iletişim kavramı bir kişi ya da grubun bir başka kişi ya da grupların kararları üzerinde etkili olarak, onları denetim altına almak veya değiştirmek amacıyla yapılan bir iletişim etkinliğidir. Etkili iletişim biçimlerinden biri olan reklamların içeriği ve hedefleri de bu tanım doğrultusunda incelenmektedir.

Bu makalenin ana amacı Türkiye'de 2001 yılında Bireysel Emeklilik Sistemi olarak kabul edilen ve 1 Ocak 2017'de yürürlüğe giren değişiklikle birlikte zorunlu hale getirilen Bireysel Emeklilik Sistemi (BES)'nin reklamlar ve kamu spotlarıyla olan ilişkisini analiz etmektir.

\section{Sosyal Güvenlik Sistemlerinin Krizi ve Bireysel Emeklilik Programları}

\section{Bireysel Emeklilik Sistemi Nedir?}

Dünya Bankası'nın 1994 yılında dağıtım temelli emeklilik sistemleri hakkındaki raporu "Yaşlııık Krizini Önleme: Yaşlıları Koruma ve Büyümeyi Sağlama Politikaları" (Averting the Old-Age Crisis: Policies to Protect the Old and Promote Growth), yeni emeklilik sistemlerinin uygulanmasının yolunu açmıştır. Bu rapora göre, kamu emeklilik sisteminin verimlilik ve dağıtım alanlarında olmak üzere iki temel problemi bulunmaktadır. Bu raporun ana savı tek bir emeklilik dağıtım fonunun başta dağıtım olmak üzere bireysel tasarruf ve sosyal sigortanın sürdürülebilirliği konusunda yetersiz olduğu ve bu noktada bireysel emeklilik sistemi uygulamasının hayata geçirilmesi üzerine kurulmuştur (Dünya Bankası, 1994: 12). Günümüzdeki üç kademeli emeklilik sisteminin farklı yaklaşımları birlikte ele alarak bireylerin çeşitli ihtiyaçlarına hizmet etmiş olduğu söylenebilir. Üç kademeli emeklilik politikasının kamusal sosyal güvenlik sistemi, mesleki emeklilik sistemi ve bireysel (özel) emeklilik sisteminden oluştuğu ifade edilmelidir (Boulier vd. 2001: 173). Kamusal emeklilik planı, emekli aylığı programının idaresinin resmi bir sosyal güvenlik kurumu tarafından yürütülmesidir, öte yandan bireysel (özel) emeklilik planı, özel bir şirket veya bireysel emeklilik fonu tarafından izlenir (OECD, 2005). Kamusal sosyal güvenlik ve mesleki

\section{$176 \mid$ ETKiLeşim |Yıl1|Sayı2| Ekim 2018}


emeklilik sisteminin yanı sıra, bireysel emeklilik planları çalışanların periyodik şekilde bireysel katkılarıyla finanse edilmiştir. Bu emeklilik sisteminin ana amacı, çalışanların yaşlılıkta sürdürülebilir bir yaşam standartlarını korumalarını sağlayan bir tasarruf hesabı oluşturmaktır (Ippolito, 1986: 6). Bu bağlamda bireysel emeklilik planı, zorunlu ve gönüllü bireysel emeklilik planı olarak ikiye ayrılmıştır. Zorunlu bireysel emeklilik planı, bireylerin genellikle belirli sayıda özel şirketler tarafından yönetilen ve devlet tarafından denetlenen mevcut bireysel emeklilik planlarından birinde katkıda bulunmalarını zorunlu kılmıştır. Mevcut emeklilik planlarından herhangi birine katkıda bulunmak için yaş ve çalışma koşulları gibi bazı uygunluk ölçütleri olabilir. Gönüllü bireysel emeklilik planında ise bireyler için kanunda herhangi bir yükümlülük bulunmamaktadır. Bunun yerine, bireyler katılmayı seçmekte özgürdürler (OECD, 2005).

\section{Türkiye'de Bireysel Emeklilik Sistemi; Emeklilik Reformunun Öncesi ve Sonrası}

Emeklilik reformundan önce Türkiye'deki sosyal güvenlik sistemi, özel ve kamu sektörü çalışanları için SSK (Sosyal Sigortalar Kurumu), devlet memurları için Emekli Sandığı (ES) ve serbest meslek sahipleri için, Esnaf ve Sanatkârlar ve Diğer Bağımsız Çalışanlar Sosyal Sigortalar Kurumu (BAĞ-KUR) olarak üç aугı kurum tarafından yürütülmekteydi. Fakat bu üç kurumun finansal sürdürülebilirliği mali ve idari krizlerle sarsıldı ve bu krizler kurumların yıpranmasına neden oldu. 1999'daki mevcut hükümet, mali açığı azaltmak için ilk reforma teşebbüs etmiştir, ancak köklü değişiklik paketi 2006 yılındaki sosyal güvenlik reformu ile hayata geçirilmiştir. Mayıs 2006'da ve Ocak 2007'de yürürlüğe giren sosyal güvenlik idari reform yasası ve sağlıkta reform yasası ile mevcut üç sosyal güvenlik kurumu Sosyal Güvenlik Kurumu (SGK) çatısı altında birleştirilmiştir. Ayrıca, Almanya'nın sosyal sigorta politikası temel alınarak hazırlanan mesleğe dayalı sigorta sistemi de değiştirilmiş ve Genel Sağlık Sigortası (GSS) olarak adlandırılan, gelir beyanına dayalı bir prim ödeme sistemi uygulanmaya başlanmıştır.

Araştırmaya konu olan Bireysel Emeklilik Sistemi ise, Türkiye Büyük Millet Meclisi (TBMM) tarafından 28 Mart 2001 tarihinde Bireysel Emeklilik Tasarruf ve Yatırım Sistemi Kanunu'yla (Resmî Gazete, 2001) kabul edilmiştir. Gönüllü katılım esasına dayanan bireysel emeklilik sistemi kanunu daha önce Demokratik Sol Parti (DSP) başkanlığında parlamentoya getirilse de Adalet ve Kalkınma Partisi (AKP) döneminde kanunlaştırıldı (Yılmaz, 2016). Bu mevzuattan sonra Türkiye'de Bireysel Emeklilik Sistemi (BES) sayıları süreç içerisinde artan bireysel emeklilik şirketleri tarafından yürütülmeye başlandı. Bu politikanın temel amacı, bireysel emeklilik hesaplarına dayalı bir fon sistemi oluşturulması olarak gösterildi. Bu sistem, Türkiye'deki mevcut kamusal ve dağıtım esaslı sosyal güvenlik sisteminin bir tamamlayıcısı olarak çalıştı ve gönüllü katılım ve bireysel katkıya dayanan iki temel noktaya sahipti. 2013 yılından itibaren, devlet tarafından bireysel emeklilik politikasını popülerleştirmek için bireysel emeklilik sisteminin katılımcılarına yüzde 25 oranında maddi destek sağlandı. Sistemin katılımcıları, devlet katkısı olan miktara ise belirli koşullarda sahip 
olabiliyorlar. Bu koşullar ise, yaş sınırı ile emeklilik gerçekleştiğinde, maluliyet ve/veya vefat durumlarıdır (Yılmaz, 2016).

1 Ocak 2017'de yürürlüğe giren Zorunlu Bireysel Emeklilik Sistemi, zorunlu otomatik katılım maddesi nedeniyle mevcut bireysel emeklilik sisteminden ayrılmaktadır. Bu yeni düzenleme Türkiye vatandaşı olan 45 yaşın altındaki tüm çalışanların, zorunlu bireysel emeklilik planına işverenler aracılığıyla dâhil edilmesini ve kişilerin istekleri doğrultusunda sistemden çıkmalarını öngörmektedir. Mevzuata göre, Zorunlu Bireysel Emeklilik Sistemi'ni desteklemek amacı ile yüzde 25 devlet katkısına ek olarak sisteme yeni katılan kişilerin emeklilik hesaplarına 1.000 TL eklenecektir. İşverenler Hazine Müsteşarlığı tarafından yetkilendirilmiş sigorta şirketlerinden biriyle sözleşme yapacak ve çalışanların emeklilik katkı payları belirlenmiş fonlarda toplanarak işlem görecektir.

Bireysel Emeklilik Sistemi'nin ulusal ekonomide tasarruf konusunda çok önemli bir mekanizma olduğu, politika aktörleri tarafından sıklıkla vurgulanmaktadır. Naczyk (2014), hükümetlerin yatırım ve istihdam alanında sağlayıcı bir rolü üstlenerek özelleştirilmiş emeklilik rejimlerini stratejik olarak desteklediğini vurgulamıştır. Bireysel emeklilik fonları katılımcıların ikinci bahar hayalini gerçekleştirmenin ötesinde, hükümetler için yatırım ve istihdam alanında kaynak teşkil etmektedir. Türkiye'de bireysel emeklilik sisteminin başlangıcından 2010 yılına kadar, bireysel emeklilik fonlarının yatırım ve istihdamın yanı sıra kamu borçlanması noktasında da önemli bir mali kaynak olduğu analiz edilmiştir (Gökbayrak, 2010). Hisse senetlerine göre getirisi daha düşük olan kamu borçlanma senetlerinin tercih edilmesi, Türkiye'deki bireysel emeklilik sistemi katılımcılarının fon tercihlerinin yorumu açısından anlamlıdır. 2010 yılını takip eden 2011 ve 2012 yıllarında da sözleşme türlerine göre katılımcıların fon grubu tercihlerinde kamu borçlanma senedi $\% 50,43$ ve $\% 49,80$ 'lük oranı ile diğer fon tercihlerini geride bırakmıştır (EGM, 2011 ve 2012). Emeklilik Gözetim Merkezi'nin yıllık raporlarına göre, kamu borçlanma senedi halen ağırlığını korumaktadır, bununla birlikte likit ve kamu borçlanma (YP) senetlerinin yükselişte olduğu söylenebilir (Tablo 1).

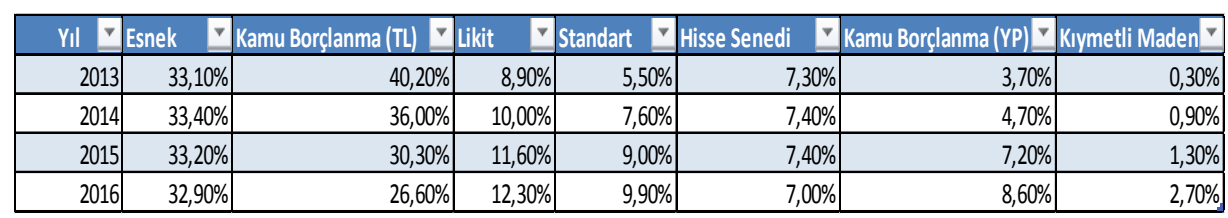

Tablo 1: Yaş Dağılımına Göre 2003-2011 Yılları Arası Toplam Katılımcı Sayısı ve Katılımciların Toplam Fon Tutarı (TL)

(Emeklilik Gözetim Merkezi, Bireysel Emeklilik Sistemi Gelişim Raporları 2013-2016)

Uthoff (1998) ise kamuya dayalı dağıtım esaslı emeklilik sistemlerinin (Pay-As-You-Go) dönüşümünü üç ana nedene bağlamıştır. Bu nedenler sırasıyla; emeklilik fonlarının uzun vadede yatırım sermayesi kaynağı olması, bireyselleşen emeklilik fonlarının finansal aracıların büyümesini ve çeşitlenmesini

\section{8 | ETKileşim | Yıl1|Sayı2|Ekim 2018}


sağlaması ve özel emeklilik sisteminde biriken fonların var olan kamu emeklilik fonlarına ek olarak ulusal tasarruf oranını arttırması ve dolaylı yoldan ekonomik büyüme sağlaması olarak sıralanabilir (Uthoff, 1998). Türkiye'deki bireysel emeklilik sisteminin gönüllülük esasından zorunluluk ilkesine dönüşümü düşünüldüğünde bu üç neden öne çıkmaktadır. Bu çalışma çerçevesinde, bireysel emeklilik fonlarının, hükümet açısından ekonomiyi desteklemek için bir yatırım ve sermaye kaynağı olarak değerlendirildiği ve bireysel emeklilik fonlarındaki büyümenin finans sektöründe bir gelişme olarak yorumlandığı savunulmaktadır.

\section{Bireysel Emeklilik Programı'nın Gelişim Dinamikleri}

Emeklilik Gözetim Merkezi'nin raporlarına göre 2003 yılında 15.245 ile başlayan katılımcı sayısı 2009 yılının sonunda 1.988 .322 olurken, bu sayı 2011 yılının sonunda 2.641.843'e ulaşmıştır. Aynı dönemde katılımcıların toplam fon büyüklüğü 9.000.212.294 TL'den 14.329.771.986'ya yükselmiştir (Tablo 2).

\begin{tabular}{|c|c|c|c|c|c|c|c|}
\hline$\nabla$ & 25 Yaş Altı & 25-34 Yaş & 35-44 Yaş & 45-55 Yaş & 56 Yaş ve Üzeri & Toplam Katilımcı Sayısı & Katlımcıların Toplam Fon Tutarı (TL) \\
\hline 2003 & 827 & 5.342 & 4.998 & 3.723 & 355 & 15.245 & \\
\hline 2004 & 27.323 & 132.011 & 106.193 & 44.593 & 4.137 & 314.257 & \\
\hline 2005 & 56.266 & 277.643 & 223.730 & 103.017 & 12.040 & 672.696 & \\
\hline 2006 & 80.185 & 428.632 & 360.283 & 177.769 & 26.781 & 1.073 .650 & 2.814.938.925 \\
\hline 2007 & 106.925 & 579.060 & 485.578 & 246.928 & 39.213 & 1.457 .704 & 4.566 .383 .316 \\
\hline 2008 & 122.129 & 687.539 & 581.450 & 302.390 & 51.846 & 1.745 .354 & 6.372 .756 .623 \\
\hline 2009 & 130.082 & 768.511 & 662.383 & 361.400 & 65.946 & 1.988 .322 & 9.000 .212 .294 \\
\hline 2010 & 136.970 & 869.568 & 755.898 & 433.448 & 85.594 & 2.281 .478 & 12.011 .986 .651 \\
\hline 2011 & 156.101 & 988.187 & 881.490 & 503.092 & 112.973 & 2.641 .843 & 14.329 .771 .986 \\
\hline
\end{tabular}

Tablo 2: Yaş Dağılımına Göre 2003-2011 Yılları Arası Toplam Katılımcı Sayısı ve Katılımcıların Toplam Fon Tutarı (TL)

(Emeklilik Gözetim Merkezi, Bireysel Emeklilik Sistemi Gelişim Raporları)

Bireysel Emeklilik Sistemi'ne zorunlu katılım uygulamasına kadar geçen süre içerisinde, 2001-2016 döneminde hem katılımcı sayısının, hem de toplam fon büyüklüğünün birlikte büyümeye devam ettiği görülmektedir (Tablo 3).

\begin{tabular}{|l|r|r|r|}
\hline YII & $\nabla$ & Toplam Katılımcı SayıSI & Katılımcıların Toplam Fon Tutarı \\
\hline 2012 & 3.128 .130 & 20.346 .290 .278 \\
\hline 2013 & 4.153 .055 & 25.145 .718 .418 \\
\hline 2014 & 5.092 .871 & 34.793 .077 .808 \\
\hline 2015 & 6.038 .432 & 42.979 .056 .589 \\
\hline 2016 & 6.627 .025 & 53.409 .391 .715 \\
\hline
\end{tabular}

Tablo 3: 2012 -2016 Yılları Arasında Toplam Katılımcı Sayısı ve Toplam Fon Tutarı (TL) (Emeklilik Gözetim Merkezi, Bireysel Emeklilik Sistemi Gelişim Raporları)

Bu sayı 2016 yılının sonunda 6 milyon 732 bin 706'ya ulaşmıştır. Aynı dönemde katılımcıların toplam fon büyüklüğü 9.000.212.294 TL'den 56 milyar 159 milyon liraya yükselmiştir (EGM, 2006, 2015). 2001-2016 döneminde hem 
katılımcı sayısının hem de toplam fon büyüklüğünün birlikte büyümeye devam ettiği görülmektedir. 18.08.2017 tarihindeki verilere göre ise katılımcıların fon tutarı 62.495,0 milyon TL'ye ulaşmıştır (EGM, 2017).

Emeklilik Gözetim Merkezi'nden alınan son verilere göre katılımcıların profili şu şekilde özetlenebilir: Bireysel emeklilik sözleşmelerini korumak isteyen katılımcıların çoğunun 35-44 yaş aralığına (\%34,05) ait olduğu, çoğunlukla Marmara Bölgesi'nde ikamet ettiği ve yine yüksek oranda üniversite mezunu olduğu (\%86,23) görülmektedir (Grafik 1). 25-34 yaş aralığındaki katılımcıların oranı \%28,55 ile ikinci sıradadır, 45-55 yaş aralığının payı ise \%23,04 olarak belirtilmiştir (Grafik 2).

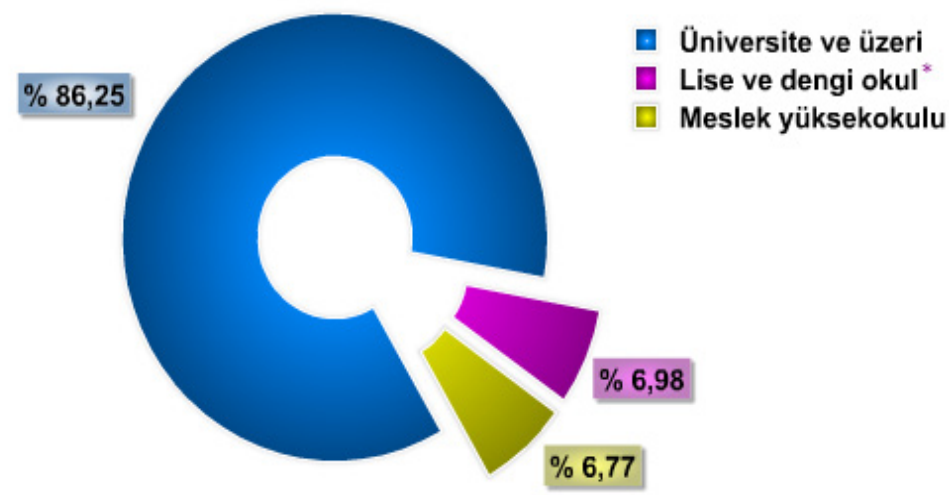

Grafik 1: Emeklilik Gözetim Merkezi, Eğitim Durumuna Göre Aracı Dağıtımı-18.08.2017 (Emeklilik Gözetim Merkezi, Bireysel Emeklilik Sistemi Temel Göstergeleri)

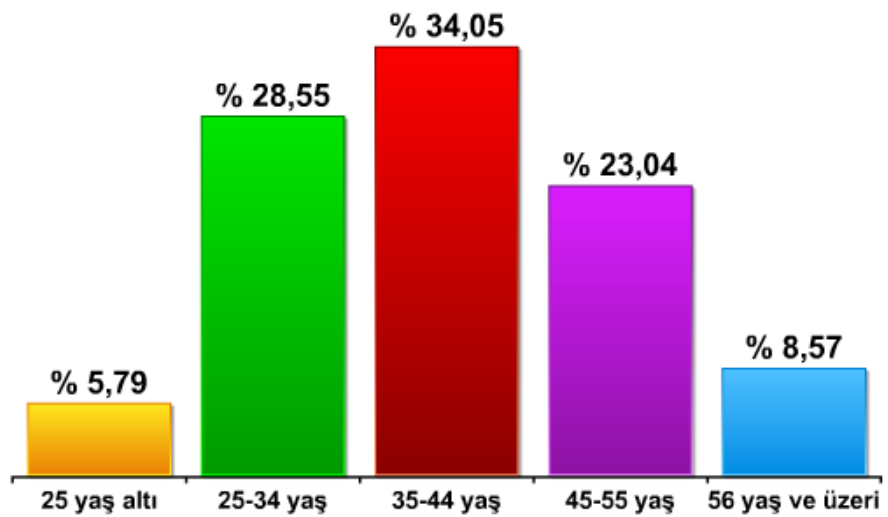

Grafik 2. Emeklilik Gözetim Merkezi, Katılımcı Yaş Dağılımı-18.08.2017 (Emeklilik Gözetim Merkezi, Bireysel Emeklilik Sistemi Temel Göstergeleri)

180 | ETKileşim | Yıl 1 Sayı 2 |Ekim 2018 
Katılımcıların en yoğun yaşadığı illerin verisi ise, Türkiye'nin sosyoekonomik haritasına uygunluk göstermektedir; 'beyaz yakalı' olarak tabir edilen maaşlı çalışanların yoğunlukla yaşadığı üç büyükşehir olan İstanbul $(\% 28,5)$, Ankara $(\% 9,2)$ ve İzmir $(\% 7,0)$ 'de bireysel emeklilik sistemine katılım diğer illere göre daha yüksektir (Grafik 3).

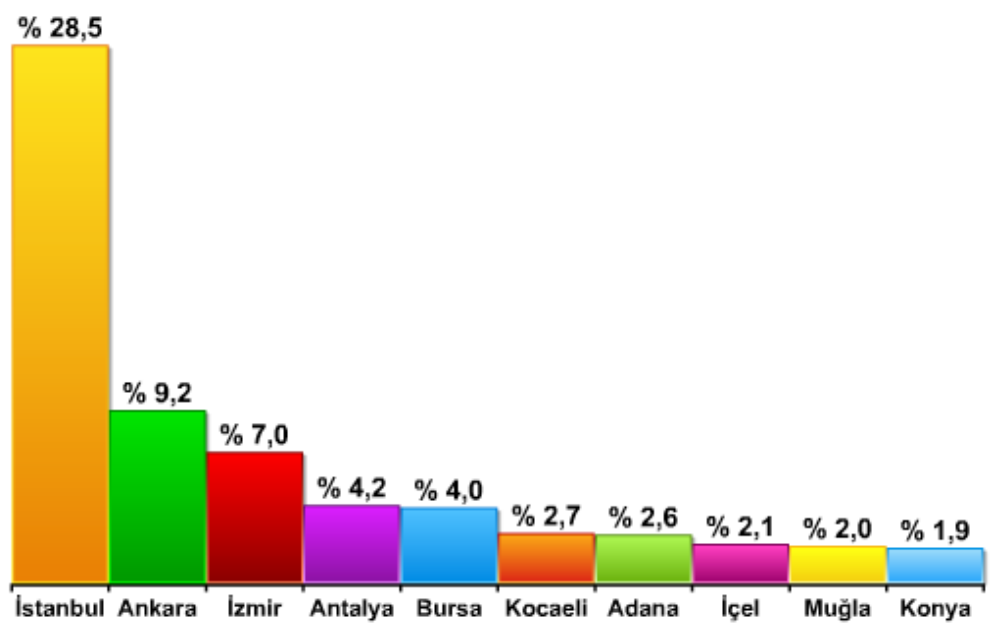

Grafik 3. Emeklilik Gözetim Merkezi, En Fazla Katılımcının Yerleşik Olduğu ilk 10 il-18.08.2017 (Emeklilik Gözetim Merkezi, Bireysel Emeklilik Sistemi Temel Göstergeleri)

2003-2016 döneminde bireysel emeklilik sistemine katılan katılımcıların, ödeme dönemi için yıllık yerine aylık katkıda bulunmayı tercih etmişlerdir. 1 Ocak 2017'de yürürlüğe giren Zorunlu Bireysel Emeklilik Sistemi, zorunlu otomatik katılım maddesi nedeniyle mevcut bireysel emeklilik sisteminden ayrılmaktadır. Bu yeni düzenlemeyle birlikte Türkiye vatandaşı olan 45 yaşın altındaki tüm çalışanların, zorunlu bireysel emeklilik planına işverenler aracılığıyla dâhil edilmesi ve kişilerin istekleri doğrultusunda sistemden çıkmaları öngörülmektedir. Mevzuata göre Zorunlu Bireysel Emeklilik Sistemi'ni desteklemek amacı ile yüzde 25 devlet katkısına ek olarak, sisteme yeni katılan kişilerin emeklilik hesaplarına 1.000 TL eklenecektir. İşverenler, Hazine Müsteşarlığı tarafından yetkilendirilmiş sigorta şirketlerinden biriyle sözleşme yapacak ve çalışanların emeklilik katkı payları belirlenmiş fonlarda toplanarak işlem görecektir. Hem bireysel emeklilik fonlarının hem de katılımcıların ve sözleşmelerin toplam sayısının bu rakamlara ve 2017 yılının Ocak ayında yürürlüğe giren Zorunlu Bireysel Emeklilik yasasına bakarak büyümeye devam edeceğini söyleyebiliriz.

\section{Bireysel Emeklilik Sistemi ve Reklamlar}

Etkileyici iletişim biçimlerinden biri olan reklamlarla ilgili yapılan araştırmalara göre reklam mesajlarının özellikleri; görüş farkı, hitap etme yaklaşımları ve ya- 
pısal özellikler başlıkları altında incelenmektedir (Gürgen, 1990). Bu bağlamda reklamların hedeflenen tüketici kitleye iletilmesi ve ilgili tüketicilerin kararları üzerinde etkili olması reklamın ana amacıdır. Hitap şekillerinden biri olan "korkuya dayalı hitap etme" ise genellikle sigorta ile ilgili olan reklamlarda karşımıza çıkmaktadır (Gürgen, 1990). Bu hitap şeklinde tüketiciye iletilecek mesaj korkuyu hedef alacak şekilde düzenlenmektedir, ancak korkuya dayalı hitap etme biçiminin hedef alıcılar üzerinde karmaşık bir etkiye sahip olduğu da vurgulanmaktadır (Gürgen, 1990). Bu noktada, korkuya dayalı hitap etme şeklindeki bir mesaj aynı zamanda tüketiciye sunulmak istenen hizmetin veya malın yararını da ortaya koymalıdır. William McGuire'in (1978) de belirttiği gibi, tüketiciler üzerinde orta düzeyde korkuya sebep olan reklam mesajları az veya yüksek düzeyde korkuya neden olan mesajlardan daha etkilidir.

Türkiye'de yayınlanan bireysel emeklilik temalı reklamlarda göze çarpan husus, bu reklamlarda iletilmek istenen mesajın çoğunlukla hedef alıcıya korkuya dayalı hitap etme biçiminde sunulmasıdır. Bireysel emeklilik şirketlerinin reklamlarının ana içeriğini, hedef alıcıların geleceği için vurgulanan tasarruf mesajları oluşturmaktadır. Bu mesajlarda kişilerin tasarruf yapmasının, kendi gelecekleri ve ekonomik güvenceleri için zorunlu olduğu vurgulanmaktadır. Öte yandan, tasarruf amaçlı oluşturulan bireysel emeklilik fonlarının yeni düzenlemelerle birlikte getirilen yüzde 25 devlet katkısı ve ilk giriş ödemesiyle birlikte hedef alıcılar için daha faydalı olduğu da iletilmektedir. Örneğin sektörün önde gelen şirketlerden birinin ödüllü reklamındaki ana mesaj, hedef alıcıları yarını düşünmeye ve emekliliği için vakit kaybetmeden tasarruf yapmaya davet etmektir. Bu reklamda saatlerine bakan insanlar, bireysel emeklilik sistemine geçmek için uygun zamanın geldiğini düşünmekte, bireysel emeklilik sisteminin yeni düzenlemeleri hakkında bilgi almak ve sisteme dâhil olmak için harekete geçmektedir. Bu sayede reklamlar, hem korkuya hem de alınacak hizmetin faydasına odaklanmaktadır.

\section{Tartışma ve Sonuç}

Yukarıda sunulan bilgiler ışığında Türkiye'nin bireysel emeklilik politikasının değişiminin, neo-liberal politikaların Türk refah rejiminin dönüşümündeki rolünü tartışmak için bir gösterge olarak değerlendirilebileceği düşünülmektedir. Sistemin uygulanmaya başlandığı 2003 yılından, zorunluluk esasına göre yürütüldüğü 2017 yılına kadar geçen zamandaki verilere bakıldığında sisteme katılım oranının ve sistemde biriken fon tutarının birlikte artış gösterdiği görülmektedir. Bu çalışma çerçevesinde ise, ilgili büyüme bireysel emeklilik fonu katılımcılarına ekonomik anlamda özgür bir emeklilik hayatının sağlanmasından ziyade, dağıtım esaslı kamusal sosyal güvenlik sisteminin bir krizi olarak yorumlanmaktadır. Özellikle gelir düzeyi düşük ve geçici-düzensiz çalışan geniş bir nüfusa sahip olan Türkiye'de, bireysel emeklilik sisteminin sermaye piyasalarını derinleştirici etkisi nedeniyle, esas olarak piyasalar açısından işlevsel olduğu vurgulanmaktadır.

\section{$182 \mid$ ETKileşim | Yıl1|Sayı $2 \mid$ Ekim 2018}


Çok basamaklı emeklilik sistemleri çalışanların emeklilik güvencelerini kamu dağıtımlı emeklilik sistemlerine göre daha kırılgan hale getirmiştir. Kamusal emeklilik sistemleri kişilere emeklilik yaşamlarında istihdam statüsüne orantılı olarak ve belirlenmiş maaş esasına göre sabit bir emeklilik maaşı sunar. Bu bağlamda, kamusal emeklilik sistemlerinin bireysel emeklilik sistemlerine göre, istihdam/maaş statüsü esaslı ve sabit emeklilik maaşı getirili bir sistem olduğu görülmektedir. Bireysel emeklilik sistemi ise prim düzeylerinin sabit, maaş düzeyinin ise değişken olduğu ve katılımcılara belirli bir emekli maaşı garantisi sunulmayan bir sistemdir. Sisteme katılan ve fon tercihleriyle birikimleri aracı kurumlar vasıtasıyla değerlendirilen katılıcımlar yaptıkları mali birikimin olası kaybıyla karşı karşıya kalmaktadır. Bu çok basamaklı yapı, katılımcıları sistemin olası riskleri ve mali kayıplarına karşı tam anlamıyla korumamakta ve katılımcıların emeklilik hayatlarında yaşayabilecekleri finansal bir krizin olumsuz sonuçlarına karşı onları daha korumasız bırakmaktadır.

Öte yandan bireysel emeklilik politikasındaki bu değişim, dağıtım esaslı emeklilik sisteminin özelleştirilmesi ve mevcut emeklilik haklarının ve menfaatlerinin kısıtlanması olmak üzere iki noktada yoğunlaşan karşı savlara yol açmıştır. Hükümetin zorunlu BES politikasına tepki olarak farklı kanatlardan sendikalar, mesleki dernekler ve sivil toplum örgütleri arasında bir fikir birliğine varıldığı görülmektedir. Türkiye Kamu-Sen, Türk Eğitim-Sen, Devrimci İsçi Sendikaları Konfederasyonu, Türk Tabipler Birliği ve Bankaları BES-leme gibi farklı duyarlılıklara sahip kurumlar zorunlu bireysel emeklilik sistemine karşı kendi üyelerini bilgilendirmiş ve düzenlemeyi çalışan hakları bağlamında eleştirmişlerdir. Bugünkü mevcut tabloya baktığımızda Türkiye'de bireysel emeklilik sisteminin kapsamının genişlemeye devam edeceği ve büyümesini sürdüreceği düşünülmektedir.

\section{Kaynakça}

Ankara Tabip Odası. (2017). Zorunlu Bireysel Emeklilik Sistemi Hakkında Bilgilendirme. http://www.ato.org.tr/news/show/180. 15.03.2018.

Apak, S. ve Kamer, H, T. (2010). “Türkiye'de Bireysel Emeklilik Sisteminin Gelişimi”. Ekonomi Bilimleri Dergisi. 2(2). 121-129.

AvivaSA. (Haziran, 2008). Tasarrufa Yönlendiren Reklam Filmi AvivaSA'ya Ödül Getirdi. https://www.avivasa.com.tr/web/53-366-1-1/avivasa_tr/hakkimizda/ iletisim_faaliyetleri_-_basin_odasi/tasarrufa_yonlendiren_reklam_filmi_ avivasaya_odul_getirdi_. 15 Mart 2018.

(22 Kasım 2012). AvivaSA Yeni Reklam Filmiyle Tasarruf İçin "Tam Zamanı" Diyor. https://www.avivasa.com.tr/web/53-432-1-1/avivasa_tr/hakkimizda/iletisim_faaliyetleri_-_basin_odasi/avivasa_yeni_reklam_filmiyle_ tasarruf_icin_tam_zamani_diyor. 15 Mart 2018.

Bonoli, G. (2000). The Politics of Pension Reform: Institutions and Policy Change in Western Europe. Cambridge: Cambridge University Press. 
Boulier, J., Shao, J, H., Grégory, T. (2001). "Optimal Management Under Stochastic Interest Rates: The Case of a Protected Defined Contribution Pension Fund". Insurance: Mathematics and Economics. 28(2). 173-189.

Emeklilik Gözetim Merkezi. (2003). Bireysel Emeklilik Sistemi Gelişim Raporu. İstanbul: Emeklilik Gözetim Merkezi.

(2004). Bireysel Emeklilik Sistemi Gelişim Raporu. İstanbul: Emeklilik Gözetim Merkezi.

(2005). Bireysel Emeklilik Sistemi Gelişim Raporu. İstanbul: Emeklilik Gözetim Merkezi.

(2006). Bireysel Emeklilik Sistemi Gelişim Raporu. İstanbul: Emeklilik Gözetim Merkezi.

(2007). Bireysel Emeklilik Sistemi Gelişim Raporu. İstanbul: Emeklilik Gözetim Merkezi.

(2008). Bireysel Emeklilik Sistemi Gelişim Raporu. İstanbul: Emeklilik Gözetim Merkezi.

(2009). Bireysel Emeklilik Sistemi Gelişim Raporu. İstanbul: Emeklilik Gözetim Merkezi.

(2010). Bireysel Emeklilik Sistemi Gelişim Raporu. İstanbul: Emeklilik Gözetim Merkezi.

(2011). Bireysel Emeklilik Sistemi Gelişim Raporu. İstanbul: Emeklilik Gözetim Merkezi.

(2012). Bireysel Emeklilik Sistemi Gelişim Raporu. İstanbul: Emeklilik Gözetim Merkezi.

(2013). Bireysel Emeklilik Sistemi Gelişim Raporu. İstanbul: Emeklilik Gözetim Merkezi.

(2014). Bireysel Emeklilik Sistemi Gelişim Raporu. İstanbul: Emeklilik Gözetim Merkezi.

(2015). Bireysel Emeklilik Sistemi Gelişim Raporu. İstanbul: Emeklilik Gözetim Merkezi.

(2016). Bireysel Emeklilik Sistemi Gelişim Raporu. İstanbul: Emeklilik Gözetim Merkezi.

(2017). BES Temel Göstergeleri; 2015. http://www.egm.org.tr/weblink/BESgostergeler.html. 25 Temmuz 2017.

(2017). BES Temel Göstergeleri; 2017. http://www.egm.org.tr/weblink/BESgostergeler.asp. 27 Ağustos 2017.

Gökbayrak, Ş. (2010). Refah Devletinin Dönüşümü ve Özel Emeklilik Programları. Ankara: Siyasal Kitabevi.

Ippolito, R, A. (1986). Pensions, Economics and Public Policy. ABD: Pension Research Council.

184| ETKileşim | Yıl1|Sayı2|Ekim 2018 
Naczyk, M. ve Bruno, P. (2014). "Feed the Beast: Finance Capitalism and the Spread of Pension Privatisation in Europe". SSRN. http://ssrn.com/abstract=2551521. 27 Ağustos 2017.

NTV. (2017). "DiSK'ten BES Açıklaması”. http://www.ntv.com.tr/ekonomi/disktenbes-aciklamasi,ovOffCe0TUOzaXQEwZESIg. 15 Mart 2018.

OECD. (2005). Private Pensions. Organization for Economic Cooperation and Development.

Özbek, N. (2006). Cumhuriyet Türkiyesi'nde Sosyal Güvenlik ve Sosyal Politikalar. İstanbul: Emeklilik Gözetim Merkezi.

Resmî Gazete. (7 Nisan 2001). Bireysel Emeklilik Tasarruf ve Yatırım Sistemi Kanunu. No. 4632, Tertip: 5, Sayısı: 24366. http://www.mevzuat.gov.tr/Metin1.Aspx?MevzuatKod=1.5.4632\&Mevzuatlliski=0\&sourceXmlSearch=\&Tur=1\&Tertip=5\&No=4632. 15 Mart 2018.

"Türkiye Kamu-Sen'den BES Açıklaması: Olmayan Şeyin Tasarrufu Yapılmaz". (2017). http://www.kpsscafe.com.tr/kamu-personeli/turkiye-kamu-senden-bes-aciklamasi-olmayan-seyin-tasarrufu-h68442.html. 15 Mart 2018.

Uthoff, A. (1998). Pension Funds, the Financing of Transition Costs and Financial Markets Development: Lessons from the Chilean Privatization Reform. Santiago: Financing Development Series.

World Bank. (1994). Averting the Old Age Crisis, Policies to Protect the Old and Promote Growth. ABD: World Bank Publications, Oxford University Press.

Yılmaz, V. (2016). "Türkiye'de Emekliliğin Özelleştirilmesi ve Zorunlu Özel Bireysel Emeklilik Sistemine Geçiş: Katı Olan Her Şey Buharlaşıyor". Birikim Dergisi. http://www.birikimdergisi.com/guncel-yazilar/7699/turkiye-de-emekliligin-ozellestirilmesi-ve-zorunlu-ozel-bireysel-emeklilik-sistemine-gecis-kati-olan-her-sey-buharlasiyor\#.WDrNCFmLTIU. 15 Mart 2018. 